\title{
Substituição do farelo de soja por levedura de cana-de-açúcar em rações para frangos de corte ${ }^{1}$
}

\author{
Replacing soybean meal by yeast sugar cane in broiler-chicken diets
}

\author{
Ednardo Rodrigues Freitas ${ }^{2 *}$, Raffaella Castro Lima ${ }^{3}$, Roberto Batista da Silva ${ }^{3}$, Francislene Silveira Sucupira ${ }^{3}$ e \\ Roseane Madeira Bezerra ${ }^{3}$
}

\begin{abstract}
RESUMO - Esta pesquisa objetivou avaliar os efeitos da substituição da proteína do farelo de soja (FS) pela da levedura de cana-de-açúcar (LEV) em rações de frangos contendo farelo da castanha de caju (FCC). O total de 325 pintos machos com um dia de idade foram distribuídos em delineamento inteiramente casualizado, com cinco rações e cinco repetições de treze aves. Foram testadas cinco rações contendo $20 \%$ de FCC e os níveis de $0 ; 5 ; 10 ; 15$ e $20 \%$ de substituição da proteína do FS pela da LEV. Conforme análise de regressão, houve efeito quadrático da substituição da proteína do FS pela da LE V sobre o consumo de ração e conversão alimentar e linear sobre o ganho de peso, na fase inicial (1 a 21 dias). Contudo, a substituição em níveis de até $20 \%$ não prejudicou significativamente o desempenho nas diferentes fases de criação e não alterou as características de carcaça em relação ao controle. Pelo estudo econômico, a substituição da proteína do FS pela da LEV se mostrou viável até o nível de 20\%. Pode-se concluir que, em rações para frangos de corte, contendo $20 \%$ de FCC, a proteína do FS pode ser substituída pela da LEV em até $20 \%$.
\end{abstract}

Palavras-chave: Alimentação de frangos de corte. Alimento alternativo. Levedura. Subproduto da agroindústria.

\begin{abstract}
This research aimed to evaluate the effects of substituting the protein from soybean meal (SM) by yeast sugar cane (YSC) in broiler-chicken diets containing cashew nut meal (CNM). A total of 325 male chicks at one day old, were distributed completely randomly among five feeds with five replications of thirteen birds each. We tested five diets containing 20\% CNM each and the levels of 0, 5, 10, 15 and 20\% protein replacement of SM by YSC. According to regression analysis, there was a quadratic effect on feed intake and feed conversion by the protein replacement of SM by the YSC, and a linear effect on weight gain in the initial phase (1-21 days). However, substitution at levels up to $20 \%$ did not significantly impair performance at any of the different stages, and did not affect the carcass characteristics when compared to the control group. According to the economic study, the protein replacement of SM by YSC proved feasible up to $20 \%$. It can be concluded that, for broiler-chicken diets containing $20 \% \mathrm{CNM}$, the SM protein can be replaced up to $20 \%$ YSC.
\end{abstract}

Key words: Broiler feeding. Alternative feed. Yeast. Agribusiness by-produts.

\footnotetext{
* Autor para correspondência

${ }^{1}$ Recebido para publicação em 21/09/2010; aprovado em 20/06/2012

Parte da Dissertação do terceiro autor apresentada no Departamento de Zootecnia/UFC

${ }_{2}^{2}$ Departamento de Zootecnia, Centro de Ciências Agrárias/UFC, Campus do Pici, Bloco 808, Fortaleza-CE, Brasil, 60.021-970, ednardo@ufc.br

${ }^{3}$ Programa de Pós-Graduação em Zootecnia, CCA/UFC, Fortaleza-CE, Brasil, raffazoo@yahoo.com.br, robmessias@yahoo.com.br, francislene. silveira@yahoo.com.br, rosembes@yahoo.com.br
} 


\section{INTRODUÇÃO}

Buscando a redução nos custos com a alimentação, que chegam a representar cerca de $70 \%$ do custo total de produção, pesquisadores têm avaliado a utilização de alimentos alternativos na formulação de rações para aves. Nesse contexto, os subprodutos das agroindústrias regionais têm sido avaliados, pois geralmente são ingredientes adquiridos a baixo custo e podem ser facilmente encontrados em certas áreas, em determinada época do ano.

Na região Nordeste e especificamente no Estado do Ceará, alguns subprodutos gerados pela agroindústria têm potencialidade para o uso na composição de rações para aves. Entre eles, pode-se destacar a levedura de canade-açúcar (Saccharomyces cerevisiae), obtida durante a produção de aguardente que, segundo Silva et al. (2008), apresenta composição química que o potencializa como ingrediente para as rações de aves, podendo substituir parte da proteína do farelo de soja.

Algumas pesquisas com a utilização de levedura de recuperação, obtida de diferentes processos industriais de fermentação alcoólica, na alimentação de frangos de corte são encontrados na literatura nacional. Os resultados dessas pesquisas indicam uma variação de 3 a $10 \%$ na quantidade de levedura a ser utilizada nas rações de frangos de corte (SILVA et al., 2003). Grangeiro et al. (2001) constataram que a composição química da levedura de recuperação oriunda da industria de produção de aguardente diferia em relação à composição apresentada pela Empresa brasileira de pesquisa agropecuária (1991) e, que é viável a inclusão de 7,5\% dessa levedura na ração de frangos de corte. Silva et al. (2003) recomendaram a inclusão de $10 \%$ de levedura na ração de frangos de corte.

As diferenças entre as recomendações do melhor nível de inclusão da levedura de recuperação nas rações de frangos têm sido atribuídas ao fato desse alimento estar sujeito a variações no seu valor nutricional, devido a alterações de composição química, que depende do método de obtenção, que por sua vez varia quanto ao substrato, microrganismo e método de secagem utilizados. Silva et al. (2008) constataram diferenças na composição e valor nutricional para aves de dois tipos de leveduras obtidas da industria de aguardente em relação aos apresentados para a levedura da industria sucroalcooleira apresentados por Rostagno et al. (2005).

Diante do exposto anteriormente, o objetivo da pesquisa foi avaliar o efeito da substituição parcial da proteína bruta do farelo de soja pela da levedura de cana-de-açúcar obtida durante a produção de aguardente em rações contendo farelo da castanha de caju sobre o desempenho de frangos de corte.

\section{MATERIAL E MÉTODOS}

$\mathrm{O}$ experimento foi conduzido em um galpão de alvenaria com dimensões de $15 \mathrm{~m} \times 10 \mathrm{~m}$, coberto por telhas de barro, piso cimentado, pé direito com $3,5 \mathrm{~m}$, orientado longitudinalmente no sentido leste-oeste e dividido em boxes de $1,5 \mathrm{~m}$ x 1,0 m.

Foram utilizados 325 pintos machos da linhagem Ag Ross 308, com um dia de idade, distribuídos em um delineamento experimental inteiramente casualizado, com cinco tratamentos e cinco repetições de treze aves cada. Foram testadas cinco rações contendo $20 \%$ de FCC e os níveis de $0 ; 5 ; 10 ; 15$ e $20 \%$ de substituição da proteína da proteína bruta do farelo de soja pela da levedura de cana-de-açúcar.

A levedura de cana-de-açúcar, utilizada nas rações, foi recuperada do processo de fermentação alcoólica para produção de aguardente e seca em rolo, cedida pela Indústria Ypióca, localizada em Fortaleza, Ceará.

Logo após a chegada ao aviário, os pintos foram pesados $(45,54 \pm 0,74 \mathrm{~g})$ e distribuídos com base no peso para que todas as parcelas tivessem peso médio semelhante. Em cada boxe foram colocadas treze aves, que foram criadas em piso coberto com cama de raspa de madeira em uma espessura de $10 \mathrm{~cm}$.

A iluminação artificial do galpão foi realizada com lâmpadas fluorescentes de 40 watts, distribuídas a uma altura de $2,40 \mathrm{~m}$ do piso, permitindo uma iluminação uniforme para todos os boxes. O programa de luz durante todo período experimental foi de $23 \mathrm{~h}$ luz (natural + artificial)/dia, com o objetivo de estimular o consumo de ração.

Os pintos vieram vacinados do incubatório contra Marek e Gumboro e aos sete dias de idade foram vacinados contra Newcastle por via ocular e aos quatorze dias contra Gumboro, via água. Durante todo o período experimental os dados de temperatura e umidade relativa do ar foram coletados no início da manhã e no final da tarde. As temperaturas foram registradas por termômetros de máxima e mínima e a umidade relativa do ar através de termo-higrômetro de bulbo seco e úmido.

Para o cálculo das rações experimentais (Tabela 1 e 2), foram consideradas as exigências nutricionais recomendadas pelo National Research Council (1994) para as fases inicial (1 a 21 dias de idade) e final (22 a 42 dias). Para todas as fases de criação das aves, as rações experimentais foram calculadas para serem isocalóricas, isocálcicas, isofosfóricas e isoaminoacídicas para metionina + cistina. A exigência de lisina foi atendida para o mínimo recomendado. 
Tabela 1 - Composição percentual e calculada das rações experimentais utilizadas para frangos de corte na fase inicial ( 1 a 21 dias)

\begin{tabular}{|c|c|c|c|c|c|}
\hline \multirow[t]{2}{*}{ Ingredientes } & \multicolumn{5}{|c|}{$\begin{array}{l}\text { Níveis de substituição da proteína do farelo de soja pela proteína da levedura de } \\
\text { cana- de- açúcar }(\%)\end{array}$} \\
\hline & 0 & 5 & 10 & 15 & 20 \\
\hline Milho grãos & 41,23 & 40,50 & 39,76 & 39,02 & 39,00 \\
\hline Farelo de soja & 29,19 & 27,73 & 26,27 & 24,81 & 23,35 \\
\hline Farelo de castanha de caju & 20,00 & 20,00 & 20,00 & 20,00 & 20,00 \\
\hline Levedura de cana- de- açúcar & 0,00 & 3,40 & 6,80 & 10,20 & 13,60 \\
\hline Fosfato monobicálcio & 1,37 & 1,32 & 1,27 & 1,22 & 1,29 \\
\hline Calcário & 1,00 & 0,99 & 0,99 & 0,98 & 0,90 \\
\hline Suplemento vitamínico-mineral ${ }^{1}$ & 0,40 & 0,40 & 0,40 & 0,40 & 0,40 \\
\hline Sal comum & 0,34 & 0,25 & 0,16 & 0,07 & 0,00 \\
\hline Dl-Metionina & 0,22 & 0,23 & 0,23 & 0,24 & 0,24 \\
\hline L-Lisina & 0,00 & 0,00 & 0,00 & 0,00 & 0,00 \\
\hline Inerte $^{2}$ & 6,24 & 5,18 & 4,13 & 3,07 & 1,23 \\
\hline Total & 100,00 & 100,00 & 100,00 & 100,00 & 100,00 \\
\hline \multicolumn{6}{|l|}{ Composição calculada } \\
\hline Energia metabolizável (kcal kg) & $2.950,00$ & $2.950,00$ & $2.950,00$ & $2.950,00$ & $2.950,00$ \\
\hline Proteína bruta $(\%)$ & 21,20 & 21,13 & 21,06 & 20,99 & 20,98 \\
\hline Matéria seca (\%) & 88,64 & 88,52 & 88,40 & 88,28 & 87,97 \\
\hline Extrato etéreo (\%) & 10,74 & 10,72 & 10,70 & 10,69 & 10,7 \\
\hline Fibra bruta $(\%)$ & 3,88 & 3,81 & 3,74 & 3,67 & 3,62 \\
\hline Fibra detergente ácido (\%) & 7,75 & 8,06 & 8,36 & 8,67 & 9,00 \\
\hline Fibra detergente neutro $(\%)$ & 14,27 & 15,45 & 16,62 & 17,80 & 19,06 \\
\hline Cálcio (\%) & 0,92 & 0,92 & 0,92 & 0,92 & 0,92 \\
\hline Fósforo disponível (\%) & 0,41 & 0,41 & 0,41 & 0,41 & 0,44 \\
\hline Sódio (\%) & 0,18 & 0,18 & 0,18 & 0,18 & 0,19 \\
\hline Lisina total $(\%)$ & 1,09 & 1,09 & 1,09 & 1,09 & 1,10 \\
\hline Metionina + cistina total $(\%)$ & 0,83 & 0,83 & 0,83 & 0,83 & 0,83 \\
\hline Metionina total $(\%)$ & 0,54 & 0,55 & 0,55 & 0,55 & 0,55 \\
\hline Treonina total $(\%)$ & 0,81 & 0,81 & 0,82 & 0,82 & 0,83 \\
\hline Triptofano total (\%) & 0,27 & 0,27 & 0,27 & 0,27 & 0,27 \\
\hline
\end{tabular}

${ }^{1}$ Suplemento vitamínico-mineral (composição por kg do produto): antioxidante 25g; cobre 2000mg; zinco $17500 \mathrm{mg}$; ferro $12500 \mathrm{mg}$; iodo $187,50 \mathrm{mg}$; manganês $18750 \mathrm{mg}$; promotor de crescimento $25,50 \mathrm{~g}$; coccidiostático $27,50 \mathrm{~g}$; selênio $75 \mathrm{mg}$; violeta de genciana $3 \mathrm{~g}$; vitamina A $2.000 .000 \mathrm{UI}$; vitamina B1 $450 \mathrm{mg}$; vitamina B12 $3000 \mathrm{mcg}$; vitamina B $21500 \mathrm{mg}$; vitamina B6 $700 \mathrm{mg}$; vitamina D3 500.000 UI; vitamina E $3750 \mathrm{mg}$; vitamina K $3450 \mathrm{mg}$; biotina $15 \mathrm{mg}$; acido fólico $250 \mathrm{mg}$; acido pantotênico $3750 \mathrm{mg}$; colina $105.000 \mathrm{mg}$; niacina $10000 \mathrm{mg}$; Veículo q.s.p.- $1000 \mathrm{~g}$; ${ }^{2} \mathrm{Areia}$ lavada 
Tabela 2 - Composição percentual e calculada das rações experimentais utilizadas para frangos de corte na fase final (22 a 42 dias)

\begin{tabular}{|c|c|c|c|c|c|}
\hline \multirow[t]{2}{*}{ Ingredientes } & \multicolumn{5}{|c|}{$\begin{array}{l}\text { Níveis de substituição da proteína do farelo de soja pela proteína da levedura de } \\
\text { cana- de- açúcar }(\%)\end{array}$} \\
\hline & 0 & 5 & 10 & 15 & 20 \\
\hline Milho grãos & 49,22 & 48,32 & 47,40 & 46,49 & 45,56 \\
\hline Farelo de soja & 24,13 & 22,93 & 21,72 & 20,51 & 19,31 \\
\hline Farelo de castanha de caju & 20,00 & 20,00 & 20,00 & 20,00 & 20,00 \\
\hline Levedura de cana- de- açúcar & 0,00 & 2,80 & 5,60 & 8,40 & 11,20 \\
\hline Fosfato monobicálcio & 1,03 & 0,99 & 0,96 & 0,92 & 0,88 \\
\hline Calcário & 1,11 & 1,10 & 1,09 & 1,08 & 1,08 \\
\hline Suplemento vitamínico-mineral $^{1}$ & 0,40 & 0,40 & 0,40 & 0,40 & 0,40 \\
\hline Sal comum & 0,27 & 0,19 & 0,12 & 0,05 & 0,00 \\
\hline Dl-Metionina & 0,13 & 0,13 & 0,14 & 0,14 & 0,15 \\
\hline L-Lisina & 0,00 & 0,00 & 0,00 & 0,00 & 0,00 \\
\hline Óleo de soja & 0,00 & 0,12 & 0,24 & 0,35 & 0,48 \\
\hline Inerte $^{2}$ & 3,70 & 3,02 & 2,34 & 1,66 & 1,08 \\
\hline Total & 100,00 & 100,00 & 100,00 & 100,00 & 100,00 \\
\hline \multicolumn{6}{|l|}{ Composição calculada } \\
\hline Energia Metabolizável (kcal kg) & $3.100,00$ & $3.100,00$ & $3.100,00$ & $3.100,00$ & $3.100,00$ \\
\hline Proteína bruta (\%) & 19,53 & 19,44 & 19,36 & 19,27 & 19,19 \\
\hline Matéria seca (\%) & 88,60 & 88,53 & 88,47 & 88,41 & 88,34 \\
\hline Extrato etéreo $(\%)$ & 10,94 & 10,92 & 10,90 & 10,87 & 10,85 \\
\hline Fibra bruta (\%) & 3,73 & 3,67 & 3,61 & 3,55 & 3,48 \\
\hline Fibra detergente ácido (\%) & 7,63 & 7,87 & 8,11 & 8,35 & 8,59 \\
\hline Fibra detergente neutro $(\%)$ & 14,47 & 15,40 & 16,34 & 17,27 & 18,20 \\
\hline Cálcio (\%) & 0,87 & 0,87 & 0,87 & 0,87 & 0,87 \\
\hline Fósforo disponível (\%) & 0,34 & 0,34 & 0,34 & 0,34 & 0,34 \\
\hline Sódio (\%) & 0,15 & 0,15 & 0,15 & 0,15 & 0,16 \\
\hline Lisina total $(\%)$ & 0,97 & 0,97 & 0,97 & 0,97 & 0,97 \\
\hline Metionina + cistina total $(\%)$ & 0,70 & 0,70 & 0,70 & 0,70 & 0,70 \\
\hline Metionina total $(\%)$ & 0,43 & 0,43 & 0,43 & 0,44 & 0,44 \\
\hline Treonina total $(\%)$ & 0,74 & 0,75 & 0,75 & 0,75 & 0,75 \\
\hline Triptofano total (\%) & 0,24 & 0,24 & 0,24 & 0,24 & 0,24 \\
\hline
\end{tabular}

${ }^{1}$ Suplemento vitamínico-mineral (composição por kg do produto): zinco $14000 \mathrm{mg}$; antioxidante $20 \mathrm{~g}$; cobre $1600 \mathrm{mg}$; coccidiostático 22 g; ferro $10.000 \mathrm{mg}$; iodo $150 \mathrm{mg}$; manganês $15.000 \mathrm{mg}$; promotor de crescimento $31,60 \mathrm{~g}$; selênio $60 \mathrm{mg}$; violeta de genciana $2.40 \mathrm{~g}$; vitamina A 1.400.000 UI; vitamina B1 320 mg; vitamina B12 $2000 \mathrm{mcg}$; vitamina B $21000 \mathrm{mg}$; vitamina B6 520 mg; vitamina D3 300.000 UI; vitamina E $2400 \mathrm{mg}$; vitamina K3 $300 \mathrm{mg}$; acido fólico $140 \mathrm{mg}$; acido pantotênico $2600 \mathrm{mg}$; colina $84.000 \mathrm{mg}$; niacina $7000 \mathrm{mg}$; veículo q.s.p. 1000g; ${ }^{2}$ Areia lavada

No cálculo das rações, também, foram considerados os valores de composição química e de energia metabolizável da levedura de cana-de-açúcar e do farelo da castanha de caju (Tabela 3), determinados por
Silva et al. (2008) e valores de aminoácidos propostos pela Empresa brasileira de pesquisa agropecuária (1991). Para os demais ingredientes foram considerados os dados apresentados por Rostagno et al. (2005). 
Tabela 3 - Composição proximal e valores de energia bruta e metabolizável da levedura de cana-de-açúcar e do farelo da castanha e caju utilizados para as formulações das rações para frangos de corte

\begin{tabular}{lcc}
\hline \multicolumn{1}{c}{ Constituintes } & Levedura & Farelo da castanha de caju \\
\hline Matéria Seca $(\%)^{1}$ & 86,46 & 94,74 \\
Energia bruta $(\mathrm{kcal} \mathrm{kg})^{1}$ & 3.419 & 6.075 \\
EMAn $(\mathrm{kcal} \mathrm{kg})^{1}$ & 1.698 & 4.437 \\
Proteína bruta $(\%)^{1}$ & 19,38 & 21,21 \\
Fibra bruta $(\%)^{1}$ & 0,97 & 6,72 \\
Fibra detergente ácido $(\%)^{1}$ & 13,06 & 20,34 \\
Fibra detergente neutro $(\%)^{1}$ & 43,12 & 27,25 \\
Extrato etéreo $(\%)^{1}$ & 0,85 & 44,54 \\
Matéria mineral $(\%)^{1}$ & 11,14 & 3,18 \\
Cálcio $(\%)^{1}$ & 0,59 & 0,57 \\
Fósforo $(\%)^{1}$ & 0,39 & 0,24 \\
Sódio $(\%)^{1}$ & 1,10 & 0,06 \\
Potássio $(\%)^{1}$ & 1,22 & 0,76 \\
Magnésio $(\%)^{1}$ & 0,23 & 0,25 \\
Lisina $(\%)^{2}$ & 1,28 & 0,88 \\
Metionina $(\%)^{2}$ & 0,27 & 0,31 \\
Metionina + Cistina $(\%)^{2}$ & 0,51 & 0,43 \\
Triptofano $(\%)^{2}$ & 0,32 & 0,27 \\
Treonina $(\%)^{2}$ & 0,98 & 0,75 \\
\hline
\end{tabular}

${ }^{1}$ Valores determinados e expressos na matéria natural; ${ }^{2}$ Valores calculados com base na composição da tabela da Embrapa (1991)

O nível de farelo da castanha de caju foi fixado baseando-se na viabilidade de sua inclusão nas rações para frangos de corte em até $25 \%$ (FREITAS et al., 2006) e considerando que a inclusão de $20 \%$ permitiu a maior substituição da proteína do farelo de soja pela da levedura de cana-de-açúcar, associada à menor inclusão de inerte.

Durante todo o experimento, as rações e a água foram fornecidas à vontade. A água foi oferecida em bebedouros pendulares e a ração em comedouros tubulares. As variáveis estudadas foram consumo de ração (g/ave), ganho de peso (g/ave), conversão alimentar, rendimentos de carcaça, de peito, de coxa e sobrecoxa, percentagem de penas e de gordura abdominal.

No início do experimento e aos 21 e 42 dias de idade, a ração fornecida e as sobras foram pesadas para determinar o consumo. Nesses mesmos períodos, também se procedeu à pesagem das aves de cada parcela para que o ganho de peso médio da parcela fosse calculado. A partir destes dados foi calculado a conversão alimentar.

Aos 42 dias de idade, após jejum alimentar de 6 horas, todas as aves foram pesadas e foram selecionados dois frangos de cada boxe com pesos próximos ao peso médio da parcela $( \pm 100 \mathrm{~g})$. As aves escolhidas foram identificadas e abatidas por deslocamento cervical, sangradas, escaldadas (água a $60{ }^{\circ} \mathrm{C}$ por 3 minutos), depenadas e evisceradas. Para a determinação da proporção de penas (expresso em percentagem do peso vivo), as aves foram pesadas após a sangria e a retirada das penas.

As carcaças limpas, sem cabeça, pescoço e pés, foram pesadas para determinação do rendimento de carcaça (expresso em percentagem do peso vivo). Em seguida, realizou-se os cortes para retirada do peito inteiro e coxa+sobrecoxa, os quais foram pesados para o cálculo da porcentagem de peito e coxa+sobrecoxa. A gordura abdominal de cada ave, considerada como todo o tecido adiposo existente em volta da cloaca e aderido à moela, foi retirada e pesada. Os dados de rendimento de peito, coxa+sobrecoxa e de gordura abdominal foram obtidos pela relação entre o peso da parte avaliado e o peso da carcaça quente.

Para verificar a viabilidade econômica da substituição parcial da proteína bruta do FS pela proteína bruta da LEV em rações contendo farelo da castanha de caju, determinou-se inicialmente o custo da ração (CR) por 
quilograma de peso vivo ganho (Yi), segundo a equação 1 proposta por Bellaver et al. (1985):

$Y i=\frac{(Q i x P i)}{G i}$

onde: Yi - custo da ração por quilograma de peso vivo ganho no i-ésimo tratamento; $\mathrm{Pi}$ - preço por quilograma da ração utilizada no i-ésimo tratamento; Qi - quantidade de ração consumida no i-ésimo tratamento, Gi - ganho de peso do i-ésimo tratamento.

Em seguida, foram calculados o Índice de Eficiência Econômica (IEE) e o Índice de Custo (IC) propostos por Fialho et al. (1992) (Equação 2):

$$
I E E=\left(\frac{M C e i}{C T e i}\right) \times 100
$$

onde, MCei = Menor custo da ração por quilograma ganho observado entre tratamentos, CTei = Custo do tratamento i considerado.

As análises estatísticas dos dados foram realizadas utilizando-seo SAS (2000). Os graus de liberdade referentes aos níveis de substituição da proteína do farelo de soja pela proteína da levedura, excluindo-se o nível zero de substituição (controle), foram desdobrados em polinômios e para estabelecer o melhor nível de substituição utilizouse o modelo quadrático. Para comparação dos resultados obtidos com cada um dos níveis de substituição em relação aos obtidos com o nível zero de substituição (controle), foi utilizado o teste de Dunnett. Em todas as análises foi considerado o nível de significância de 5\%.

\section{RESULTADOS E DISCUSSÃO}

As médias de temperatura ambiente mínima e máxima e umidade relativa no galpão durante $\mathrm{o}$ experimento foram $28,09^{\circ} \mathrm{C} \pm 0,72,30,24^{\circ} \mathrm{C} \pm 1,0$ e $76 \%$, respectivamente.

Os resultados médios do desempenho dos frangos de corte alimentados com diferentes níveis de substituição da proteína bruta do farelo de soja pela proteína bruta da levedura de cana-de-açúcar são apresentados na Tabela 4.

Na análise de regressão para o consumo de ração, excluindo a ração controle (nível zero de substituição), observou-se efeito significativo apenas para os dados da fase inicial. Nessa fase houve efeito quadrático, indicando que a substituição parcial da proteína bruta do farelo de soja pela proteína bruta da levedura de cana-de-açúcar promoveu aumento no consumo de ração até cerca de $12,08 \%$ de substituição, diminuindo em seguida. $\mathrm{Na}$ comparação das médias do consumo de ração, também se observou diferença significativa apenas nos resultados da fase inicial. Os diferentes níveis de substituição da proteína do farelo de soja pela da levedura resultaram em maior ingestão de alimento em relação ao obtido para as aves do grupo controle.

Segundo Perdomo et al. (2004), a baixa digestibilidade da parede celular da levedura reduz a

Tabela 4 - Desempenho de frangos de corte alimentados com diferentes níveis de substituição da proteína bruta do farelo de soja pela proteína bruta da levedura de cana- de- açúcar

\begin{tabular}{|c|c|c|c|c|c|c|c|}
\hline \multirow[t]{2}{*}{ Variáveis } & \multicolumn{5}{|c|}{$\begin{array}{l}\text { Níveis de substituição da proteína do FS pela proteína da LEV } \\
(\%)\end{array}$} & \multirow[t]{2}{*}{ Média } & \multirow[t]{2}{*}{$\mathrm{CV}(\%)$} \\
\hline & 0 & 5 & 10 & 15 & 20 & & \\
\hline \multicolumn{8}{|c|}{ Fase inicial (1 a 21 dias) } \\
\hline Consumo de ração (g ave $)^{2}$ & $1.174,00$ & $1.285,00 *$ & $1.368,00^{*}$ & $1.312,00^{*}$ & $1.291,00^{*}$ & $1.286,00$ & 4,22 \\
\hline Ganho de peso $(\mathrm{g} \text { ave })^{3}$ & 625,00 & $723,00 *$ & $693,00 *$ & $692,00 *$ & $677,00 *$ & 682,00 & 4,30 \\
\hline Conversão alimentar ${ }^{4}$ & 1,88 & 1,78 & 1,97 & 1,90 & 1,91 & 1,89 & 3,55 \\
\hline \multicolumn{8}{|c|}{ Período total (1 a 42 dias) } \\
\hline Consumo de ração (g ave) & 4553,00 & 4210,00 & 4632,00 & 4747,00 & 4403,00 & $4.520,00$ & 8,54 \\
\hline Ganho de peso (g ave $)^{5}$ & 2114,00 & 1949,00 & 2257,00 & 2245,00 & 2211,00 & $2.164,00$ & 5,01 \\
\hline Conversão alimentar & 2,16 & 2,16 & 2,05 & 2,12 & 2,00 & 2,09 & 8,97 \\
\hline
\end{tabular}

*Diferente em relação ao controle pelo teste de Dunnett $(5 \%) ;{ }^{1}$ coeficiente de variação $(\%) ;{ }^{2}$ Regressão - efeito quadrático - Y = $1197,76+$ $26,56 \mathrm{x}-1,02 \mathrm{x}^{2}$; prob. $=0,034 \mathrm{R}^{2}=0,93 ;{ }^{3}$ Regressão - efeito linear $-\mathrm{Y}=729,75-2,70 \mathrm{x}$; prob. $=0,036 \mathrm{R}^{2}=0,95 ;{ }^{4} \mathrm{Regressão}-$ efeito quadrático $-\mathrm{Y}=1,60+0,50 \mathrm{x}-0,002 \mathrm{x}^{2}$; prob. $=0,024 \mathrm{R}^{2}=0,93 ;{ }^{5}$ Regressão - efeito quadrático $-\mathrm{Y}=1552,08+100,02 \mathrm{x}-3,39 \mathrm{x}^{2} ;$ prob. $=0,003 \mathrm{R}^{2}=$ 0,$55 ; \mathrm{FS}=$ farelo de soja; LEV = levedura de cana-de-açúcar 
digestibilidade dosnutrientes daraçãoe, consequentemente, o seu valor energético. Dessa forma, considerando que a energia é o principal fator que controla o consumo de alimento pelos frangos de corte e que as rações foram calculadas para serem isoenergéticas, pode-se inferir que o aumento no consumo de ração inicial com a maior inclusão de levedura tenha sido uma tentativa das aves em atender suas exigências energéticas em razão do menor aproveitamento de energia da ração.

A redução no consumo em níveis superiores a $12,08 \%$ de substituição pode estar associada às características físicas da levedura, pois segundo Maia et al. (2002) a levedura é um alimento altamente aglutinante que leva à formação de aglomerados no fundo dos comedouros e pode causar aderência no bico das aves, favorecendo a redução no consumo. Por outro lado, o maior consumo das aves alimentadas com os diferentes níveis de substituição da levedura em relação ao controle, pode ser atribuído à maior demanda de nutrientes, visto que estas aves também apresentaram maior ganho de peso.

Diferentes influências da inclusão de levedura na ração de frangos sobre o consumo de ração são relatadas na literatura. Grangeiro et al. (2001) não verificaram influências dos níveis crescente de levedura até 7,5\% sobre essa variável. Entretanto, Silva et al. (2003) constataram que a inclusão de levedura na ração até $10 \%$ reduziu o consumo dos frangos de corte nos períodos de 1 a 21 e de 1 a 42 dias de idade.

Para o ganho de peso, na fase inicial houve redução linear ( $\mathrm{Y}=729,75-2,70 \mathrm{x})$ com o aumento dos níveis de substituição da proteína do farelo de soja pela proteína da levedura de cana-de-açúcar, de modo que para cada $1 \%$ de substituição houve redução média de $2,70 \mathrm{~g}$ no ganho de peso. No período total de criação houve efeito quadrático $\left(\mathrm{Y}=1552,08+100,02 \mathrm{x}-3,39 \mathrm{x}^{2}\right)$, observando-se que o ganho de peso aumentou com os níveis crescentes de substituição atingindo o máximo com cerca de $14,75 \%$ de substituição. Conforme o teste de médias, na fase inicial as aves alimentadas com ração contendo levedura de canade-açúcar apresentaram ganho de peso significativamente maiores em relação às aves alimentadas com a ração controle. Para o período total de criação não houve diferença significativa no ganho de peso das aves submetidas aos diferentes tratamentos.

Além de serem ingeridos, os nutrientes das rações devem ser degradados e absorvidos para se tornarem disponíveis nos processos metabólicos. Assim, uma menor disponibilidade de nutrientes nas rações contendo níveis elevados de levedura de cana-de-açúcar seria a responsável pelo menor ganho de peso na fase inicial e com níveis superiores a $15 \%$ de substituição no período total de criação. Silva et al. (2003) apresentaram resultados de pesquisas nos quais níveis de inclusão da levedura acima de $10 \%$ promoveram queda no ganho de peso dos frangos de corte. Esse efeito foi atribuído às características físicas da parede celular da levedura que contribuem para a redução da disponibilidade dos nutrientes (PERDOMO et al., 2004)e, consequentemente, para o menor ganho de peso.

$\mathrm{Na}$ literatura, os resultados da influência da inclusão de levedura na ração sobre o ganho de peso são divergentes. Grangeiro et al. (2001) verificaram que a inclusão de levedura obtida da indústria de aguardente em níveis de até $7,5 \%$ não influenciou significativamente o ganho de peso dos frangos de corte nas diferentes fases de criação. Entretanto, Silva et al. (2003) verificaram que a inclusão de $10 \%$ de levedura obtida da indústria de álcool na ração de frangos prejudicou o ganho de peso no período de 1 a 21 dias e de 1 a 42 dias de idade.

Para conversão alimentar, observou-se efeito significativo na análise de regressão apenas na fase inicial. Nessa fase houve efeito quadrático $(\mathrm{Y}=1,60+$ $\left.0,50 x-0,002 x^{2}\right)$ que demonstrou uma piora na conversão alimentar até o nível $12,5 \%$ de substituição da proteína do farelo de soja pela da levedura, melhorando em seguida com níveis superiores. Com a comparação das médias, observou-se que na fase inicial e no período total de criação não houve diferença significativa dos resultados obtidos para os níveis de substituição da proteína avaliados quando comparados à ração controle.

O efeito observado para a conversão alimentar dos frangos de corte alimentados com os diferentes níveis de substituição pode ser atribuído ao menor aproveitamento dos nutrientes da ração, visto que o aumento no consumo de ração não foi acompanhado de um aumento no ganho de peso.

Assim como para o consumo e o ganho de peso, os efeitos da inclusão da levedura na ração sobre a conversão alimentar dos frangos de corte são variáveis. Grangeiro et al. (2001) não verificaram diferença significativa na conversão alimentar das aves alimentadas com diferentes níveis crescentes de inclusão de levedura de cana-de-açúcar na ração até 7,5\%. Entretanto, Silva et al. (2003) constataram que, embora o consumo de ração e o ganho de peso tenham diminuído no período de 1 a 21 dias de idade, a conversão alimentar dos frangos neste período não foi influenciada significativamente pela inclusão de levedura na ração. Porém, na avaliação do período total de criação foi verificado que a inclusão de levedura no nível de $10 \%$ prejudicou a conversão alimentar.

As divergências na literatura da influência dos níveis de levedura sobre o consumo de ração, ganho de peso e conversão alimentar dos frangos de corte, bem 
como em relação aos resultados obtidos na presente pesquisa podem estar associadas aos níveis de inclusão testados, mas principalmente devido às características desse alimento. Como já mencionado, a levedura de recuperação, obtida dos processos fermentativos da cana-de-açúcar, está sujeita a variações no seu valor nutricional, devido a alterações de composição química, que depende do método de obtenção, que por sua vez varia quanto ao substrato e microrganismo utilizados e método de secagem.

Vale ressaltar que as diferenças entre os resultados de desempenho na fase inicial e no período total podem decorrer da recuperação do desempenho na fase de crescimento (21 a 42 dias) associada a um crescimento compensatório possibilitado por uma menor inclusão do alimento avaliado na ração dessa fase e uma maior capacidade de digestão das aves com o avançar da idade. Também é possível que o aumento no coeficiente de variação dos dados obtidos para o período total tenha contribuído para que as possíveis diferenças não fossem detectadas.

$\mathrm{Na}$ análise de regressão das características de carcaça (Tabela 5), observou-se que não houve efeito significativo da substituição parcial da proteína do farelo de soja pela da levedura sobre o rendimento de carcaça, peito, coxa e sobrecoxa, quantidade de gordura abdominal e a percentagem de penas.

$\mathrm{Na}$ comparação das médias, observou-se que o rendimento de carcaça, peito, coxa e sobrecoxa, bem como a quantidade de gordura abdominal e a percentagem de penas, não variaram significativamente nos diferentes níveis de substituição em relação ao grupo controle.

Há relatos dos efeitos da nutrição sobre o rendimento de carcaça e a quantidade de gordura abdominal dos frangos de corte (LEESON; SUMMERS, 2001). Entretanto, as alterações nestas características, principalmente na gordura abdominal, parecem estar mais sujeitas aos efeitos do nível de energia da ração (OLIVEIRA NETO; OLIVEIRA; DONZELE, 2000) e das relações energia: proteína ou energia:aminoácidos nas rações. Nesse contexto, a inclusão de um alimento em rações calculadas para serem isonutrientes poderia alterar as características de carcaça se o valor nutricional do alimento adicionado não tivesse sido corretamente avaliado, alterando as relações mencionadas anteriormente. Assim, a ausência de variação sobre as características de carcaça verificada na presente pesquisa pode ser considerada como resultado esperado. Avaliando os efeitos da inclusão de levedura de recuperação na ração de frangos de corte, Grangeiro et al. (2001) e Silva et al. (2003) também não verificaram influências significativas da inclusão desse alimento sobre o rendimento de carcaça e quantidade de gordura abdominal dos frangos.

$\mathrm{Na}$ análise de regressão para viabilidade econômica (Tabela 6) houve efeito significativo na fase inicial e no período total de criação das aves.

$\mathrm{Na}$ fase inicial, houve efeito quadrático para o custo das rações por quilograma de ganho de peso vivo $\left(\mathrm{Y}=0,964+0,028 \mathrm{x}-0,001 \mathrm{x}^{2}\right)$, índice de custo $\left(Y=91,80+2,64 x-0,097 x^{2}\right)$ e índice de eficiência econômica ( $\left.\mathrm{Y}=106,67-26,56 \mathrm{x}+1,02 \mathrm{x}^{2}\right)$. Conforme os resultados, à medida que a percentagem de substituição da proteína do farelo de soja pela da levedura aumentou houve aumento no custo das rações por quilograma de ganho de peso vivo e no índice de custo, atingindo valores máximos estimados com cerca de 14,00 e 13,61\% de substituição, respectivamente. Esses níveis de substituição correspondem a 9,52 e 9,25\% de inclusão da levedura nas rações.

Em função dos resultados obtidos para as variáveis descritas anteriormente, o índice de eficiência econômica

Tabela 5 - Características de carcaça de frangos alimentados com rações sob diferentes níveis de substituição parcial da proteína bruta do farelo de soja pela proteína bruta da levedura de cana- de- açúcar

\begin{tabular}{|c|c|c|c|c|c|c|c|}
\hline \multirow{2}{*}{ Variáveis } & \multicolumn{5}{|c|}{$\begin{array}{l}\text { Níveis de substituição da proteína do FS pela proteína da } \\
\text { LEV }(\%)\end{array}$} & \multirow{2}{*}{ Média } & \multirow{2}{*}{$\begin{array}{l}\text { CV } \\
(\%)^{1}\end{array}$} \\
\hline & 0 & 5 & 10 & 15 & 20 & & \\
\hline Rendimento de carcaça (\%) & 74,31 & 72,59 & 74,38 & 74,07 & 74,22 & 73,92 & 2,40 \\
\hline Rendimento de peito (\%) & 31,65 & 31,44 & 31,48 & 31,93 & 31,05 & 31,51 & 4,40 \\
\hline Rendimento de coxa + sobrecoxa $(\%)$ & 30,90 & 31,12 & 30,79 & 30,70 & 30,51 & 31,81 & 2,57 \\
\hline Percentagem de pena $(\%)$ & 3,24 & 2,74 & 3,05 & 3,36 & 3,19 & 3,13 & 10,64 \\
\hline Gordura abdominal (\%) & 1,94 & 1,96 & 1,85 & 2,01 & 2,08 & 1,97 & 21,19 \\
\hline
\end{tabular}

${ }^{1}$ Coeficiente de variação (\%); FS - farelo de soja; LEV - levedura de cana- de- açúcar 
Tabela 6 - Viabilidade econômica em função dos níveis crescentes de substituição da proteína do farelo de soja pela proteína da levedura de cana- de- açúcar

\begin{tabular}{|c|c|c|c|c|c|c|c|}
\hline \multirow{2}{*}{ Variáveis } & \multicolumn{5}{|c|}{ Níveis de substituição da proteína do FS pela proteína da LEV } & \multirow{2}{*}{ Média } & \multirow{2}{*}{$\mathrm{CV}(\%)^{1}$} \\
\hline & 0 & 5 & 10 & 15 & 20 & & \\
\hline \multicolumn{8}{|c|}{ Fase inicial (1 a 21 dias) } \\
\hline Custo Ração $(\mathrm{R} \$)^{2}$ & 1,14 & $1,06^{*}$ & 1,17 & 1,11 & 1,12 & 1,12 & 3,50 \\
\hline Índice Custo $(\%)^{3}$ & 108,00 & 100,00 & 112,00 & 106,00 & 107,00 & 107,04 & 3,61 \\
\hline Eficiência Econômica $(\%)^{4}$ & 92,00 & $100,00^{*}$ & 90,00 & 94,00 & 94,00 & 93,63 & 3,57 \\
\hline \multicolumn{8}{|c|}{ Período total (1 a 42 dias) } \\
\hline Custo Ração $(\mathrm{R} \$)^{5}$ & 1,28 & 1,40 & 1,15 & $1,05^{*}$ & $1,07^{*}$ & 1,18 & 10,18 \\
\hline Índice Custo $(\%)^{6}$ & 122,00 & 133,00 & 110,0 & $100,00^{*}$ & $102,00^{*}$ & 112,42 & 10,20 \\
\hline Eficiência Econômica $(\%)^{7}$ & 83,00 & 76,00 & 92,00 & $100,00^{*}$ & 99,00 & 90,63 & 10,56 \\
\hline
\end{tabular}

*Diferentes em relação ao controle pelo teste de Dunnett (5\%); ${ }^{1}$ Coeficiente de variação $(\%) ;{ }^{2}$ Regressão - efeito quadrático $-\mathrm{Y}=0,964+$ $0,028 \mathrm{x}-0,001 \mathrm{x}^{2}$; prob. $=0,029 \mathrm{R}^{2}=0,86 ;{ }^{3}$ Regressão - efeito quadrático $-\mathrm{Y}=91,80+2,64 \mathrm{x}-0,097 \mathrm{x}^{2}$; prob. $=0,034 \mathrm{R}^{2}=0,86 ;{ }^{4} \mathrm{Regressão}$ - efeito quadrático $-\mathrm{Y}=106,67-26,56 \mathrm{x}+1,02 \mathrm{x}^{2}$; prob. $=0,040 \mathrm{R}^{2}=0,84 ;{ }^{5}$ Regressão - efeito quadrático $-\mathrm{Y}=1,77-0,088 \mathrm{x}+0,003 \mathrm{x}^{2}$; prob. $=0,015 \mathrm{R}^{2}=0,64 ;{ }^{6}$ Regressão - efeito quadrático $-\mathrm{Y}=167,24-8,196 \mathrm{x}+0,247 \mathrm{x}^{2} ;$ prob. $=0,018 \mathrm{R}^{2}=0,63 ;{ }^{7}$ Regressão - efeito quadrático $-\mathrm{Y}$ $=48,07+6,405 \mathrm{x}-0,193 \mathrm{x}^{2} ;$ prob. $=0,039 \mathrm{R}^{2}=0,55 ; \mathrm{FS}$ - farelo de soja; LEV - levedura de cana- de- açúcar

piorou à medida que a percentagem de substituição cresceu atingindo o mínimo com cerca de $13,88 \%$ de substituição, correspondendo a $9,44 \%$ de inclusão de levedura nas rações.

No período total de criação das aves, houve efeito quadrático sobre o custo das rações por quilograma de ganho de peso vivo $\left(\mathrm{Y}=1,77-0,088 \mathrm{x}+0,003 \mathrm{x}^{2}\right)$, índice de custo $\left(Y=167,24-8,196 x+0,247 x^{2}\right)$ e índice de eficiência econômica $\left(48,07+6,405 x-0,193 x^{2}\right)$. Conforme os resultados, à medida que a percentagem de substituição da proteína do farelo de soja pela da levedura aumentou o custo das rações por quilograma de ganho de peso vivo e o índice de custo reduziram, atingindo o mínimo com cerca de 14,67 e 16,59\% de substituição, respectivamente. Esses níveis de substituição correspondem a 8,21 e 9,29\%de inclusão da levedura nas rações.

Em decorrência dos resultados obtidos para o custo das rações e o índice de custo, o índice de eficiência econômica melhorou à medida que a percentagem de substituição aumentou, atingindo o máximo com cerca de $16,60 \%$ de substituição, correspondendo a $9,30 \%$ de inclusão de levedura nas rações.

$\mathrm{Na}$ comparação dos resultados pelo teste de médias, observou-se que na fase inicial houve diferença significativa apenas com o nível 5\% de substituição. Este nível resultou no menor custo das rações por quilograma de ganho de peso vivo, menor índice de custo e melhor índice de eficiência econômica. Entretanto, no período total de criação das aves, os níveis de 15 e $20 \%$ de substituições proporcionaram menor custo das rações por quilograma de ganho de peso vivo, menor índice de custo e melhor índice de eficiência econômica em relação ao grupo controle.

Os dados obtidos na presente pesquisa indicam a viabilidade econômica da substituição de até $20 \%$ da proteína do farelo de soja pela proteína da levedura em rações para frangos de corte contendo $20 \%$ de farelo de castanha de caju. Entretanto, é importante ressaltar que no cálculo das variáveis, custo das rações por quilograma de ganho de peso vivo, índice de custo e índice de eficiência econômica, são considerados as relações entre o consumo e o ganho de peso obtido para cada nível de substituição. Assim, quando existe uma proporcionalidade entre as relações consumo e ganho de peso de dois ou mais tratamentos, as diferenças no custo de produção podem ser as mesmas, independente da diferença no consumo e ganho de peso que possa ter existido anteriormente. Nesse sentido, a avaliação econômica através desses índices por si só não será o melhor indicador de quanto deve ser o nível de substituição ou de inclusão de um alimento alternativo na ração.

Considerando que em nenhuma das fases de criação, o desempenho das aves alimentadas com $20 \%$ de substituição da proteína do farelo de soja pela da levedura de cana-de-açúcar foi significativamente inferior ao obtido para o grupo controle, e que este nível também não afetou as características de carcaça e foi economicamente viável, pode-se recomendar até $20 \%$ de substituição em rações para frangos de corte contendo $20 \%$ de farelo de castanha de caju. Esse percentual de substituição resulta na inclusão de 13,66 e 11,20\% de levedura nas rações da fase inicial e final, respectivamente. 
Estes níveis de inclusão da levedura são superiores aos $10 \%$ recomendados por Silva et al. (2003) e aos 7,5\% recomendados por Grangeiro et al. (2001), para utilização da levedura de recuperação obtida da indústria de aguardente na alimentação de frangos de corte.

\section{CONCLUSÃO}

Em rações para frangos de corte contendo $20 \%$ de farelo de castanha de caju, a proteína bruta do farelo de soja pode ser substituída pela da levedura de cana-deaçúcar oriunda da indústria de produção de aguardente em níveis de até $20 \%$.

\section{AGRADECIMENTOS}

Os autores agradecem à Empresa Ypioca pela doação da levedura de cana-de-açúcar utilizada nesta pesquisa.

\section{REFERÊNCIAS}

BELLAVER, C. et al. Radícula de malte na alimentação de suínos em crescimento e terminação. Pesquisa Agropecuária Brasileira, v. 20, n. 8, p. 969-974, 1985.

EMPRESA BRASILEIRA DE PESQUISA AGROPECUÁRIA. Centro Nacional de Pesquisa de Suínos e Aves. 3. ed. Tabelas de composição química e valores energéticos de alimentos para suínos e aves. Concórdia: Embrapa-CNPSA, 1991. 97 p.

FIALHO, E. T. et al. Utilização da cevada suplementada com óleo de soja para suínos em crescimento e terminação. Pesquisa Agropecuária Brasileira, v. 27, n. 10, p. 14671475. 1992.
FREITAS, E. R. et al. Farelo de castanha de caju em rações para frangos de corte. Pesquisa Agropecuária Brasileira, v. 41, n. 6, p. 101-1006, 2006.

GRANGEIRO, M. G. A. et al. Inclusão da levedura de cana- deaçúcar (Saccharomyces cerevisiae) em dietas para frangos de corte. Revista Brasileira de Zootecnia, v. 30, n. 3, p. 766-773, 2001.

LEESON, S.; SUMMERS, D. J. Nutrition of the chicken. 4. ed. Ontario: University Books, 2001. 413 p.

MAIA, G. A. R. et al. Qualidade dos ovos de poedeiras comerciais alimentadas com levedura seca de cana-de-açucar. Pesquisa Agropecuária Brasileira, v. 37, n. 9, p. 1295-1300, 2002.

NATIONAL RESEARCH COUNCIL. Nutrient Requirements of Poultry. 9. ed. Washington: National Academy Press, 1994. $155 \mathrm{p}$.

OLIVEIRA NETO, A. R.; OLIVEIRA, R. F. M.; DONZELE, J. L. Níveis de energia metabolizável para frangos de corte no período de 22 a 42 dias de idade mantidos em ambiente termoneutro. Revista Brasileira de Zootecnia, v. 29, p. 11321140, 2000.

PERDOMO, M.C. et al. Valor nutritivo de la levadura de cerveceria (Saccharomyces cerevisiae) y de sus derivados, extracto y pared celular, en la alimentacion aviar. Archivos. Latinoamericano Production Animale, v. 12, n. 3, p. 85-89. 2004.

ROSTAGNO, H. S. et al. Tabelas brasileiras para aves e suínos: composição de alimentos e exigências nutricionais. Viçosa, MG: Suprema, 2005. 185 p.

SAS Institute. SAS Users guide: Statistics. 2. ed. Version 8. Carry, NC, 2000.

SILVA, J. D. B. et al. Utilização de diferentes níveis de levedura (Saccharomyces cerevisiae) em dietas e seus efeitos no desempenho, rendimento da carcaça e gordura abdominal em frangos de cortes Acta Scientiarum Animal Science, v. 25, n. 2, p. 285-291, 2003.

SILVA, R. B. et al. Composição química e valores de energia metabolizável subprodutos agroindustriais determinados com diferentes aves. Acta Scientiarum Animal Science, v. 30, n. 3 , p. 269-275, 2008. 